\title{
Treaty Governance, Intellectual Property ANd Biodiversity
}

\author{
John Linarelli
}

\section{INTRODUCTION}

In the past several decades international treaty regimes relevant to both biodiversity and intellectual property have proliferated. The International Convention for the Protection of New Varieties in Plants, known as the UPOV Convention, came into existence in 1961 and was amended in 1978 and 1991. The UPOV Convention directs convention parties to grant plant breeder's rights, a sui generis intellectual property right. The International Undertaking on Plant Genetic Resources for Food and Agriculture, adopted in 1983, is a nonbinding agreement intended primarily to coordinate sustainable conservation of plant genetic resources by participating governments, and as part of this remit it promotes farmers' rights. 2 The Food and Agriculture Organization (FAO) is the international institution responsible for implementing the International Undertaking. The Agreement on Trade-Related Aspects of Intellectual Property (TRIPS), a multilateral agreement of the World Trade Organization, was concluded on 15 April 1994 and entered into force on 1 January 1995. Although an international trade agreement, TRIPS is relevant to the question of ownership of rights in genetic resources relating to biodiversity. It specifies standards for the intellectual property laws of the WTO members. The International Treaty on Plant Genetic Resources became the second major instrument under the FAO umbrella to deal with intellectual property rights in plants. ${ }^{\text {B }}$ Adopted in November 2001, it is designed to supplant the International Undertaking. This recent Treaty is not yet in force. When it comes into force, it has the potential to dwarf the CBD in its relevance to the intersection of intellectual property and biodiversity. 
This article focuses on the United Nations Framework Convention on Biological Diversity (CBD), concluded on 5 June 1992 at the Rio de Janeiro Earth Summit. ${ }^{1}$ The CBD is a multilateral convention. As of the writing of this paper, 180 parties have ratified it. The European Union and all of its member states are parties to the CBD. President Clinton signed the Convention, but the United States has not ratified it. President Clinton submitted the Convention to the US Senate as is required under the US Constitution, but the Senate did not consent to it. President Bush has no interest in promoting the CBD.

The CBD is not designed as an agreement to define intellectual property rights. Rather, it is an agreement to conserve global biodiversity. To the extent that it says anything about intellectual property, it is in the context of its primary mission of trying to "mediate competing claims of industrialized and developing states." ${ }^{6}$ The CBD states its three main objectives as: (i) the conservation of biological diversity; (ii) the sustainable use of the components of biological diversity; and (iii) the fair and equitable sharing of benefits arising from the use of genetic resources. ${ }^{6}$ Genetic resources are "genetic material of actual or potential value." third objective, the fair and equitable sharing of benefits from plant genetic resources, for which intellectual property concerns are of primary relevance.

The regulation of intellectual property rights in resources associated with biodiversity is a major issue of global concern. It would be difficult to challenge the argument that no other category of legal rules affects the distribution of wealth more than property rules. The enclosure of the intellectual commons is occurring in various areas of science and technology, including in information technology and cyberspace, and in biotechnology relating to pharmaceuticals, 
medicine and human genetics. Property rights and agriculture share a longstanding historical relationship. The endowments of any society are vitally connected to agriculture because agriculture is about food production. The political economics of British agriculture in seventeenth and eighteenth centuries produced the so-called first enclosure movement, in which commons in agricultural lands areas were enclosed and the rights of small farmers in estates such as copyholds were expropriated. ${ }^{8}$ While the conflict in the first enclosure movement was over rights in real property, the conflict in the second enclosure movement is rights in intellectual property. ${ }^{2}$ Similes and metaphors abound in the literature. We are in the process of the "enclosure of the intangible commons of the mind" and the "intellectual land grab., 10 The battle for rights in intellectual property is "an information arms race with multiple sides battling for larger shares of the global knowledge pool.,

Evidence of the salience of the topic can be found in the fact that as this article is written, the CBD parties are meeting in Montreal to discuss the role of the CBD in the preservation of traditional knowledge of indigenous and local communities. The delegates are examining, among other things, "knowledge, innovations and practices of indigenous and local communities relevant to the conservation and sustainable use of biodiversity, 12 guidelines for conducting cultural, environmental and social impact assessments of development on sacred sites and on land that indigenous and local communities have traditionally used or occupied, and methods for increasing indigenous and local community participation in decision making concerning policies affecting traditional knowledge. ${ }^{13}$

The organization of this article is as follows. Part I explains what biodiversity is, in brief terms. Part II summarizes why it is important. Part III examines the main CBD articles relevant 
to intellectual property. Part IV explores how the CBD differs from other treaty regimes that deal with intellectual property. Part IV characterizes international agreements that deal with intellectual property and biodiversity as either property-oriented or commons oriented.

\section{WHAT IS BIODIVERSITY?}

There are many definitions of biodiversity. Biodiversity is short for biological diversity. CBD Article 2 defines biological diversity as "the variability among living organisms from all sources including, inter alia, terrestrial, marine and other aquatic ecosystems and the ecological complexes of which they are part; this includes diversity within species, between species and of ecosystems. 114 In its 1992 Global Biodiversity Strategy, the World Resources Institute of the World Conservation Union and United Nations Environment Programme defines biodiversity as "the totality of genes, species, and ecosystems in a region." "15 There are thus three "hierarchical categories" to which the "diversity" label affixes: diversity of genes, diversity of species and diversity of ecosystems. 16

Genetic diversity "refers to the variation of genes within species." 17 It includes "distinct populations of the same species (such as the thousands of traditional rice varieties in India) or genetic variation within a population (high among Indian rhinos, and very low among

cheetahs)." ${ }^{18}$ An example of genetic diversity in California are genetic differences in Douglas fir along the coast as opposed to those found in the Sierra mountains. Firs exhibit genetic adaptations to local conditions such as the summer fog along the coast or hot summer days in the Sierra. Same species - Douglas fir - but genetically different. 
Species diversity "refers to the variety of species within a region." various measures to assess species diversity, such as "species richness" or a more precise measurement, "taxonomic diversity", which also considers the relationship between species. The World Resources Institutes provides as an example of taxonomic diversity, "an island with two species of birds and one species of lizard has a greater taxonomic diversity than an island with three species of birds but no lizards." 미

Ecosystem diversity is defined by communities or associations of species. ${ }^{2}$ A good example of ecosystem diversity can be found in the Ynyslas estuary in Wales, a combination of grasslands, wetlands, rivers, an estuary, fresh and salt water, and the largest peat bog in Europe.

How does intellectual property relate to biodiversity? To put it very simply, firms who develop pharmaceutical products plant varieties or agricultural biotechnology can develop new products from genetic resources found in biodiversity. There are many examples, too many to discuss here. 23

\section{Why IS BIODIVERSITY PRESERVATION IMPORTANT?}

Though the answer to this question seems self evident, it is not. The reasons are mired in politics. Legal rules alone do not provide answers. I provide a way of conceptualizing reasons offered for or against biodiversity conservation. Relying on moral philosophy, the reasons fall into three categories: consequentialist, deontological and virtue ethical. I provide here summary and perhaps over simplistic illustrations of how these three approaches work to answer the question why biodiversity preservation is or is not important. These methods are not totally 
distinct from each other, but are presented here as stark contrasts in order to explain their differences. In addition, there is plenty of political philosophy that provides other ways of examining the issues.

Consequentialist thinking about biodiversity (or anything else, for that matter) concerns itself with the effects of given states of affairs. A consequentialist is willing to weigh tradeoffs or to engage in cost-benefit analysis. Utilitarianism and economics are consequential approaches to inquiring about public policy.

To the economist, the question is one of weighing costs and benefits to reach an efficient collective choice. An economist asks the question whether the social benefits of preserving a particular gene sequence, species or ecosystem outweigh its social costs. If the social costs associated with the preservation of a particular rare chaparral are greater than the social benefits from destroying a range the chaparral to build badly needed housing in southern California, then, from an economic point of view, it would be more efficient to build the houses and destroy the chaparral. Most economists argue that cost-benefit analysis is a tool for positive analysis and at most a decision procedure to help governments take decisions. To the economist, the actual decision is political and beyond the realm of the economics.

There are various approaches to utilitarianism but the utilitarian asks a question similar to that of the economist: which choice - the houses or the chaparral - produce the most happiness in society? From a Benthamite perspective of pleasures and pains, which collective choice yields the greatest pleasure and the least pain? Here, we might get the same result as the economist, though this is not always the case. 
A deontologist might find the above analysis unacceptable. A deontological approach is one that we might find a nongovernmental organization or an ecologist taking. To a deontologist, it is morally or ethically wrong to destroy a rare plant species, regardless of the consequences. We have a duty to protect rare plant species, and it is wrong to destroy them. That a substantial community of humans may benefit from the destruction of habitat is irrelevant. Environmental deontologists do not carry the day in most governments and international institutions, as the managerial approach of cost-benefit analysis tends to be more influential, particularly because politicians must answer to voters.

Virtue ethics is a revival of the Aristotelian approach to ethics, to looking at properties of character, such as courage, temperance, prudence and justice. Applying virtue ethics in the public realm, to produce a so-called "public morality" has encountered some difficulties, but so have utilitarianism and deontology. ${ }^{25}$ Legal principles can reflect virtues. ${ }^{6}$ Virtue ethics would likely ask whether the decision to build the houses (or preserve the chaparral) is just or consistent with some other virtue.

I have outlined in a very brief way three decision procedures for answering the question why biodiversity is important but I have not actually answered the question. The answer depends on which decision procedure we choose. A utilitarian might well accept substantial degradation of biodiversity if the sum of satisfactions or benefits from such degradation exceeds its displeasures or costs. An economist would take a similar approach. A deontologist cannot accept breaches of moral duties to protect the environment unless there is some rule that permits derogation, but a deontologist would be hard pressed to allow any substantial degradation. A 
virtuous person would ask whether biodiversity preservation (or degradation) furthers a virtue such as justice or prudence. The hard cases at the margins is where the ethical approach one chooses matters.

Various strands of each theory exist in the text of the CBD. Such interpretations are mired in ambiguity, but a few examples can be given. The very first paragraph of the Convention states that the parties have agreed to the Convention "[c]onscious of the intrinsic value of biological diversity and of the ecological, genetic, social, economic, scientific, educational, cultural, recreational and aesthetic values of biological diversity and its components." 27 The "intrinsic value" of biological diversity suggests a deontological approach while the remainder of the paragraph, with its reference to values external to biological diversity suggest a consequentialist approach. This is a common way of expressing values about biodiversity. One commentator expresses the value of biodiversity in consequential terms in this way:

Biological diversity is important because it is a repository of genetic information gained through long processes of biological evolution. Biological diversity is valued both for its potential use (for instance, as a source of new drugs or crops) and for its aesthetic contribution. The value derived from biological diversity (for instance, cancer-curing drygs and disease-resistant crops) far exceeds the world investment in conservation.

On the other hand, the language in the CBD on "fair and equitable" sharing of benefits arising from the use of biological diversity suggests a virtue ethical or deontological approach, looking to concepts of justice in determining sharing allocations. ${ }^{29}$ It is the clash of choices - between fairness in sharing the benefits of the use of biodiversity and maximizing use - that can create the interesting problems. If we only take into account how we can put biodiversity to its greatest use, then we will permit large multinational corporations to use traditional knowledge developed 
over centuries by indigenous communities to develop patented technologies without paying any compensation to the indigenous community, since a greater good - say cheap medicine or a virus-resistant corn - may produce benefits that far outweigh any losses to the indigenous community. It would be worth examining this point using the Rawlsian difference principle. 30 Indeed, in the absence of destruction of endangered genetic resources, we could argue that the indigenous community has suffered no loss if it is still able to use its traditional knowledge in the same way as before, unless we are willing to count foregone opportunity costs as a loss, even where the community could not convert the traditional knowledge to a patentable innovation without the assistance of the multinational. More empirical work needs to be done in order to come up with proper conclusions using the framework set forth above. I have taken only a tentative and general step. The main concern, however, seems more connected to environmental regulation than intellectual property law: the destruction of plant genetic resources as a result of urbanization and other socio-economic conditions may reduce the availability of genetic resources for innovation in the form of intellectual property.

\section{The CONVENTION ON BiOlogicAl Diversity}

\section{A. Introduction}

Nations began negotiations in earnest for a global biodiversity convention in earnest in 1991. 13 These negotiations began one year before the planned United Nations Conference on Environment and Development "Earth Summit" in Rio, held in June 1992. 32 One of the major agreements signed at Rio 1992 was the CBD. The CBD went into force on 10 July 1996, with the ratification of Cyprus as the thirtieth party to ratify, accede or approve the Convention. 3 
Intellectual property falls with the scope of the CBD but it is clearly not the only subject of concern. One of the more recent and notable developments in CBD governance was the adoption of the Cartagena Protocol on Biosafety. ${ }^{34}$ The Protocol came into force on 11 September 2003. The Protocol regulates international trade in genetically modified organisms. It is a key treaty instrument in the pending WTO dispute settlement proceeding that the United States, Canada and Argentina have brought against the EU. One of the EU's main defenses will likely be that its actions to restrict the importation of genetically modified foods were designed to comply with the Cartagena Protocol. We may thus see a question with serious implications before the WTO Dispute Settlement Body as to the consistency of multilateral trade agreements with a multilateral environmental agreement. Notably, Argentina, Canada, and the United States are not parties to the Cartagena Protocol. The pending dispute before the WTO has nothing to do with intellectual property.

\section{B. The Intellectual Property Provisions}

The CBD is comprised of forty-two articles and two annexes. This part explains the parts of the Convention relevant to intellectual property.

The Preamble sets forth the values underlying the Convention. As explained above, the Preamble identifies the "intrinsic value" of biodiversity as well as its "ecological, genetic, social, economic, scientific, educational, cultural, recreational and aesthetic values. ${ }^{35}$ These values have to be interpreted with reference to two constraints. First, the idea of sovereign equality. The Preamble states that the contracting parties reaffirm "that States have sovereign rights over

their own biological resources." Second, fair and equitable sharing of the benefits of biological 
diversity, arguably including benefits that have been converted to intellectual property. The Preamble states that the contracting parties recognize "the close and traditional dependence of many indigenous and local communities embodying traditional lifestyles on biological resources, and the desirability of sharing equitably benefits arising from the use of traditional knowledge, innovations and practices relevant to the conservation of biological diversity and the sustainable use of its components," 17 and acknowledge that "special provision is required to meet the needs of developing countries, including the provision of new and additional financial resources and appropriate access to relevant technologies," particularly for "least developed countries and small island States. ${ }^{28}$ Consistently with the Preamble, Article 1 identifies the objectives of the Convention, as:

the conservation of biological diversity, the sustainable use of its components and the fair and equitable sharing of the benefits arising out of the utilization of genetic resources, including by appropriate access to genetic resources and by appropriate transfer of relevant technologies, taking into account all rights over those resources and to technologies, and by appropriate funding. ${ }^{30}$

These provisions inform the remaining articles of the Convention on intellectual property, as will be shown below.

Traditional knowledge is not a legally recognized form of intellectual property in its own right. In Article 8, dealing with in-situ conservation, ${ }^{40}$ Article $8(\mathrm{j})$ sets forth a provision on traditional knowledge. It provides that CBD contracting parties "shall, as far as possible and appropriate" and subject to national legislation:

respect, preserve and maintain knowledge, innovations and practices of indigenous and local communities embodying traditional lifestyles relevant for the conservation and sustainable use of biological diversity and promote their wider application with the approval and involvement of the holders of such knowledge, innovations and practices and encourage the equitable sharing of the benefits arising from the utilization of such knowledge, innovations and 
practices. 11

Further, CBD Article 10(c) provides that contracting parties shall, as far as possible and appropriate, "[p]rotect and encourage customary use of biological resources in accordance with traditional cultural practices that are compatible with conservation or sustainable use requirements.

The primary obligations of countries rich in biodiversity, such as developing countries, are to provide access, and Article 15 identifies the characteristics of the laws and institutions to regulate such access. ${ }^{13}$ For those countries whose persons obtain access, Article 16 identifies the characteristics of the laws and institutions to regulate the transfer of technological innovation to the countries from which the genetic resources are obtained. ${ }^{44}$ The CBD takes a top-down stateoriented approach to controlling access to genetic resources. The CBD approach is to rely on contractual arrangements between countries rich in biodiversity and persons (usually firms) who want access. It relies on a traditional regulatory model of governance, typically used for the regulation of foreign direct investment; though now out of favor because many governments now see benefits of free flow of capital into their countries. Regulation of the availability of plant genetic resources to outside prospectors, however, may be preferable if regulatory institutions do not suffer from too many public choice ills. Regulation should be designed so that the development of intellectual property from biodiversity does not result simply in an extraction process with few if any benefits flowing to indigenous and local communities.

Under the $\mathrm{CBD}$, states have "the sovereign right to exploit their own resources pursuant to their own environmental policies, and the responsibility to ensure that activities within their 
jurisdiction or control do not cause damage to the environment of other States or of areas beyond the limits of national jurisdiction. ${ }^{45}$ CBD Article 15 implements this sovereign equality mandate. CBD Article 15.1 states, "[r]ecognizing the sovereign rights of States over their natural resources, the authority to determine access to genetic resources rests with the national governments and is subject to national legislation. ${ }^{\sqrt{6}} \mathrm{CBD}$ Article 15.4 provides that "[a]ccess, where granted, shall be on mutually agreed terms and subject to the provisions of this Article" and Article 15.5 provides that "[a]ccess to genetic resources shall be subject to prior informed consent of the Contracting Party providing such resources, unless otherwise determined by that Party.,

Various provisions of the $\mathrm{CBD}$ are concerned with the fair and equitable sharing of the benefits of genetic resources and the results of research and development relating to genetic resources, but provide few if any details on how to achieve such benefit sharing. Article 15.6 requires contracting parties to "endeavour to develop and carry out scientific research based on genetic resources provided by other Contracting Parties with the full participation of, and where possible in, such Contracting Parties. ${ }^{, 8}$ Article 15.7 requires contracting parties to share in a fair and equitable way "the results of research and development and the benefits arising from the commercial and other utilization of genetic resources with the Contracting Party providing such resources. Such sharing shall be upon mutually agreed terms. Article 19 concerns the sharing of benefits and is to be read in conjunction with Article 15. Article 19.1 requires CBD contracting parties to "take legislative, administrative or policy measures, as appropriate, to provide for the effective participation in biotechnological research activities by those Contracting Parties, especially developing countries, which provide the genetic resources for such research, 
and where feasible in such Contracting Parties." " Article 19.2 requires contracting parties to "take all practicable measures to promote and advance priority access on a fair and equitable basis by Contracting Parties, especially developing countries, to the results and benefits arising from biotechnologies based upon genetic resources provided by those Contracting Parties. Such access shall be on mutually agreed terms."

For those countries whose persons obtain access, Article 16 identifies the characteristics of the laws and institutions to regulate the transfer of technological innovation to the countries from which the genetic resources are obtained. ${ }^{22}$ In addition to the sharing of the benefits of research and development in genetic resources, the CBD contains various obligations governing the transfer of technologies that result from such research and development. Article 16.2 provides that the transfer of technology to developing countries "shall be provided and/or facilitated under fair and most favourable terms, including on concessional and preferential terms where mutually agreed, and, where necessary, in accordance with the financial mechanism established by Articles 20 and 21. ${ }^{53}$ Article 20 obligates developed countries to provide financial resources to developing countries to enable the developing countries to comply with the CBD. Article 21 requires the creation of a "financial mechanism," which the CBD Conference of the Parties is to manage, to dispense these financial resources. Finally, contracting parties are required to "take legislative, administrative or policy measures with the aim that the private sector facilitates access to, joint development and transfer of technology ... for the benefit of both governmental institutions and the private sector of developing countries ....,

The CBD deals explicitly with intellectual property rights in three potentially conflicting provisions. According to CBD Article 16.5, "[t]he Contracting Parties, recognizing that patents 
and other intellectual property rights may have an influence on the implementation of this Convention, shall cooperate ... subject to national legislation and international law in order to ensure that such rights are supportive of and do not run counter to its objectives." ${ }^{55}$ Under CBD Article 16.2, access to and transfer of technology to developing countries "shall be provided on terms which recognize and are consistent with the adequate and effective protection of intellectual property rights." $\mathrm{CBD}$ Article 16.3 requires contracting parties to "take legislative, administrative or policy measures, as appropriate, with the aim that Contracting Parties, in particular those that are developing countries which provide genetic resources, are provided access to and transfer of technology which makes use of those resources, on mutually agreed terms, including technology protected by patents and other intellectual property rights where necessary, ... and consistent with paragraphs 4 and $5 . . .$, Th These provisions are ambiguous as to whether the intellectual property rights will have to be altered to accommodate the transfer of technology to developing countries under the Convention.

\section{The Bonn Guidelines}

There have been a number of Decisions of the Conference of the Parties. A recent and notable one is the Bonn Guidelines, entitled "Access to Genetic Resources and Benefit Sharing." held at Bonn in October 2001, and adopted at the sixth meeting of the Conference of the Parties, held at the Hague in April 2002. 50 The Guidelines are just that - guidelines - they are voluntary and do not set forth the kind of mandatory language that lawyers place in instruments. Many of the contracting parties are developing countries, rich in biodiversity but poor in institutional capabilities needed to manage biodiversity in a sustainable way. The Bonn Guidelines 
essentially seek to provide details to national governments on how to implement the above CBD articles relevant to intellectual property. The Guidelines more clearly define the kinds of roles that national bodies may take in implementing the CBD provisions on access and benefit sharing. They make recommendations that are designed to make governments more attuned to stakeholder interests. Brief discussion of the Guidelines is set forth here.

One of the major tasks governments face in implementing the CBD is in producing a set of institutions for implementing the prior informed consent requirement of CBD Article 15.5. The Bonn Guidelines deal with this issue. They recommend the "basic principles of a prior informed consent system, which include "legal certainty and clarity," "access to genetic resources ... at minimum cost," transparency in restrictions on access to genetic resources and the basing of such restrictions on "legal grounds," and "[t]he consent of relevant stakeholders, such as indigenous and local communities, as appropriate to the circumstances and subject to domestic law...., 60 The Guidelines list the elements of a prior informed consent system as including the various kinds of features of a public institution that relate to natural justice or due process. ${ }^{61}$ They recommend procedures for the application process for prior informed consent. ${ }^{62}$

Another major task that governments face in implementing the CBD is in coming up with a set of "mutually agreed terms" for access to genetic resources within their borders, as CBD Article 15.7 mandates. The Guidelines recommend basic requirements for mutually agreed terms, such as the development of standard form agreements and procedures for efficient negotiation of agreements. 63 The Guidelines recommend "minimization of transaction costs" through the undertaking of efforts to promote awareness of "the Government's and relevant stakeholders' requirements for prior informed consent and contractual arrangements, of "existing 
mechanisms for applying for access, entering into arrangements and ensuring the sharing of benefits.' Transaction costs could be further minimized by developing "framework agreements, under which repeat access under expedited arrangements can be made; and "standardized material transfer agreements and benefit-sharing arrangements for similar resources and similar uses.'"f- Appendix I of the Guidelines sets forth "suggested elements" for such an agreement.

The Guidelines further provide an "indicative list of typical mutually agreed terms," which include the following:

a. Type and quantity of genetic resources, and the geographical/ecological area of activity;

b. $\quad$ Any limitations on the possible use of the material;

c. Recognition of the sovereign rights of the country of origin;

d. Capacity-building in various areas to be identified in the agreement;

e. A clause on whether the terms of the agreement in certain circumstances (e.g. change of use) can be renegotiated;

f. Whether the genetic resources can be transferred to third parties and conditions to be imposed in such cases, e.g. whether or not to pass genetic resources to third parties without ensuring that the third parties enter into similar agreements except for taxonomic and systematic research that is not related to commercialization;

g. Whether the knowledge, innovations and practices of indigenous and local communities have been respected, preserved and maintained, and whether the customary use of biological resources in accordance with traditional practices has been protected and encouraged;

h. Treatment of confidential information;

i. Provisions regarding the sharing of benefits arising from the commercial and other utilization of genetic resources and their derivatives and products. 66

The Guidelines provide substantial guidance on how to implement the benefit sharing features of the CBD. Appendix II provides a detailed list of the following potential monetary benefits: 
a. Access fees/fee per sample collected or otherwise acquired;

b. Up-front payments;

c. Milestone payments;

d. Payment of royalties;

e. Licence fees in case of commercialization;

f. Special fees to be paid to trust funds supporting conservation and sustainable use of biodiversity;

g. Salaries and preferential terms where mutually agreed;

h. Research funding;

i. Joint ventures;

j. Joint ownership of relevant intellectual property rights.

And a detailed list of potential non-monetary benefits:

a. Sharing of research and development results;

b. Collaboration, cooperation and contribution in scientific research and development programmes, particularly biotechnological research activities, where possible in the provider country;

c. Participation in product development;

d. Collaboration, cooperation and contribution in education and training;

e. Admittance to ex situ facilities of genetic resources and to databases;

f. Transfer to the provider of the genetic resources of knowledge and technology under fair and most favourable terms, including on concessional and preferential terms where agreed, in particular, knowledge and technology that make use of genetic resources, including biotechnology, or that are relevant to the conservation and sustainable utilization of biological diversity;

g. Strengthening capacities for technology transfer to user developing country Parties and to Parties that are countries with economies in transition and technology development in the country of origin that provides genetic resources. Also to facilitate abilities of indigenous and local communities to conserve and sustainably use their genetic resources;

h. Institutional capacity-building;

i. Human and material resources to strengthen the capacities for the administration and enforcement of access regulations;

j. Training related to genetic resources with the full participation of providing Parties, and where possible, in such Parties;

k. Access to scientific information relevant to conservation and sustainable use of biological diversity, including biological inventories and taxonomic studies;

1. Contributions to the local economy;

m. Research directed towards priority needs, such as health and food security, taking into account domestic uses of genetic resources in provider countries;

n. Institutional and professional relationships that can arise from an access and benefit-sharing agreement and subsequent collaborative activities;

o. Food and livelihood security benefits; 
p. Social recognition;

q. Joint ownership of relevant intellectual property rights.

Note that "joint ownership of intellectual property rights" is the last on the latter two lists. The Guidelines admit to a foundation premise of the CBD, that an intellectual property rights regime need not be the only way to allocate the benefits of biodiversity.

Finally, the Bonn Guidelines recommend that national patent offices require disclosure of the country of origin of genetic resources and of "traditional knowledge, innovations and practices of indigenous and location communities. ${ }^{, 69}$ How this recommendation will work itself out within the CBD institutions remains to be seen.

IV. COMPARing THE CBD to Other INTERnATIONAL AgREEMENTS: Divergent MODELS OF TREATY GOVERNANCE

As should be evident, the CBD is not an intellectual property treaty. It does not even say that intellectual property rights have to be granted to stakeholders in developing countries, even if they developed the traditional knowledge that led to the discovery that is being commercialized by a multinational firm. The CBD reflects one way of regulating innovation related to biodiversity. The relevant international agreements are of two kinds: property-oriented agreements and commons-oriented agreements. Property-oriented agreements are traditional in their identification of intellectual property rights and standards for such rights. Examples of such agreements are TRIPS, the European Patent Convention and the UPOV Convention. These property-oriented treaties are examined in Section A below. Commons-oriented treaties are designed more like the CBD. They do not focus solely on intellectual property rights; instead they conceptualize the concern as one of management of rights of access to biodiversity and in 
sharing of benefits of various stakeholders. Examples of such agreements are the CBD, the International Undertaking on Plant Genetic Resources and the International Treaty on Plant Genetic Resources. The latter two agreements are examined in Section B below.

\section{A. Property-Oriented Agreements}

\section{TRIPS}

TRIPS is one of the most important international agreements relevant to the allocation of rights in genetic resources in biodiversity. Although an agreement that is supposed to regulate international trade, it specifies substantive standards for the intellectual property laws of the WTO members. It is unlike any other trade agreement preceding it, unlike anything produced in the GATT/WTO framework since the GATT's humble beginnings as a provisional agreement to regulate tariffs. 00 TRIPS harmonizes intellectual property protection at a high level of protection for rights holders, and this is one of its controversial characteristics. Another is that it shifts the locus of international regulation of intellectual property rights to the WTO from other international regulatory regimes, such as the World Intellectual Property Organization (WIPO), a United Nations organization, and the International Union for the Protection of New Varieties in Plants.

The key TRIPS provision relevant to intellectual property rights in biodiversity is Article 27, entitled "Patentable Subject Matter." Article 27 provides that patents "shall be available for any inventions, whether products or processes, in all fields of technology, provided they are new, involve an inventive step and are capable of industrial application." ${ }^{12}$ WTO members must make patents available in their territories "without discrimination . . . as to the field of technology." 23 Three exceptions exist to this "any technology" standard for patentability. Article 27.2 provides 
that WTO members may exclude from patentability inventions, "the prevention within their territory of the commercial exploitation of which is necessary to protect ordre public or morality, including to protect human, animal or plant life or health or to avoid serious prejudice to the environment, provided that such exclusion is not made merely because the exploitation is prohibited by their law." 44 Article 27.3 provides that members may exclude from patentability (a) "diagnostic, therapeutic and surgical methods for the treatment of humans or animals" and (b) "plants and animals other than micro-organisms, and essentially biological processes for the production of plants or animals other than non-biological and microbiological processes.", Further, under subparagraph (b), WTO members may provide for the protection of plant varieties either by patents, or by an "effective sui generis system" or by a combination of the two methods. 76

One of the basic distinctions between sui generis protection and patents is that sui generis rights tend to be subject to various exemptions, such as a research exemption such exceptions. They would fall, at least implicitly, within the sui generis category of protection permitted under Article 27.3(b). In addition, TRIPS Article 30 provides that "[m]embers may provide limited exceptions to the exclusive rights conferred by a patent, provided that such exceptions do not unreasonably conflict with normal exploitation of the patent and do not unreasonably prejudice the legitimate interests of the patent owner, taking account of the legitimate interests of third

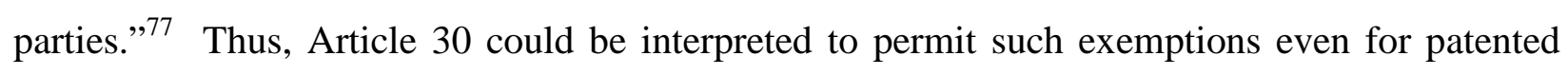
seeds and plants. 
Article 27 was negotiated in the Uruguay Round to substantially adopt the wording of Article 53(b) of the European Patent Convention, but important differences maintain. The European Patent Convention Article 53 provides:

European patents shall not be granted in respect of:

(a) inventions the publication or exploitation of which would be contrary to "ordre public" or morality, provided that the exploitation shall not be deemed to be so contrary merely because it is prohibited by law or regulation in some or all of the Contracting States;

(b) plant or animal varieties or essentially biological processes for the production of plants or animals; this provision does not apply to microbiological processes or the products thereof.

Convention Article 53 uses the term "shall" when referring to exclusions from patentability of plant varieties, but TRIPS Article 27 uses the term "may." The European Patent Convention excludes from eligibility for European patents rights in plant and animal varieties, and "essentially biological processes" for plant and animal production, but leaves the door open for rights in microbiological processes. By contrast, Article 27 leaves the policy choice to WTO members to use patents, sui generis rights, or both, to protect rights in plants and animal varieties. WTO members, in addition, may exclude from patentability "essentially biological processes" for plant and animal production, but not for the production of micro-organisms, or rights in non-biological and microbiological processes. TRIPS and the European Patent Convention are consistent.

\section{The European Patent Convention}

The Convention on the Grant of European Patents, popularly known as the European Patent Convention, came into existence on 5 October 1973 in Munich. It has thus been in 
existence long before TRIPS, and, as explained above, it in part formed the basis for language used in TRIPS Article 27.3(b). The members of the Convention include the EU member states in their capacities outside of the EU system. The Convention is not part of the EU legal system. In addition, five other European states not in the EU are members of the Convention: Cyprus, Liechtenstein, Monaco, Switzerland and Turkey. With a single application to the European Patent Office (EPO) established under the Convention, an inventor can obtain patent protection in all countries that are members of the Convention. The European level Convention and its registration system co-exist with national patent laws and national registration systems. The European patent is valid in the countries that are members of the Convention, but the interpretation and enforcement of the patents are issues for national law. 80

As explained above, Convention Article 53(b) provides that "European patents shall not be granted in respect of ... plant or animal varieties or essentially biological processes for the production of plants or animals; this provision does not apply to microbiological processes or the products thereof." 11 The term "varieties" is not defined in the Convention. The travaux préparatoires of the Convention indicates that plant varieties were excluded from patent protection principally because sui generis protection existed under the UPOV Convention, then in its 1971 version, and under national laws implementing the UPOV Convention. 2 When the European Patent Convention was drafted, plants and animals were not patentable because breeding did not result in plants and animals that could be reproduced. Genetic engineering has advanced since the early 1970 s to the point where the reproducibility objection no longer exists, and patenting is a feasible option for protection of inventions in plant and animal varieties. ${ }^{83}$ The 
decision of the European Patent Office Enlarged Board of Appeal in Novartis Transgenic Plant is a movement in that direction.

The Convention contains grounds for denying patent applications on moral grounds substantially similar to the standard found in TRIPS Article 27.2. Convention Article 53(a) prohibits the grant of patents in Europe whose invention, publication and exploitation would be contrary to ordre public or morality. ${ }^{4}$

\section{The UPOV Convention}

The International Convention for the Protection of New Varieties of Plants (UPOV Convention) was signed in Paris in 1961 and revised in 1972, 1978 and 1991. The Convention established the International Union for the Protection of New Varieties of Plants. ${ }^{85}$ When the European Patent Convention was drafted in the early 1970s, the UPOV Convention required signatories to use plant variety rights as the exclusive means of protection of rights in plant varieties. The UPOV Convention was amended in 1991 to freely permit countries to use patents, plant variety rights or both to protect rights in plant varieties. The 1991 Convention represents a substantial revision, in that it freely permits dual protection of plant varieties, by patents, sui generis rights or both. ${ }^{66}$ The original 1961 Convention required signatories to choose one form of protection for "one and the same botanical genus or species," either patents or sui generis rights. The 1978 Convention relaxed this restriction to permit countries such as the US and Japan to continue to provide dual protection if they had provided it before 31 October 1979. The 1978 revision facilitated the accession of the US and Japan to the Convention. 


\section{B. The Main Commons-Oriented Agreement: The International Treaty on Plant Genetic Resources}

The agreements that more specifically deal with plant genetic resources are to be contrasted with the traditional international agreements that deal with intellectual property. These former agreements are managed by the FAO. They were, initially, the International Undertaking on Plant Genetic Resources for Food and Agriculture, a nonbinding agreement that will, subsequently, be superseded by the International Treaty on Plant Genetic Resources for Food and Agriculture. The basics of these agreements are discussed here.

The first of these agreements, the International Undertaking, was the principal instrument within the FAO system for the regulation of intellectual property rights in plant genetic resources, until the International Treaty was signed. ${ }^{8.8}$ The International Treaty is not yet in force, so the status of the International Undertaking is uncertain. The International Undertaking was adopted in 1983. It was initially proposed as legally binding, but the parties could not reach agreement. It was adopted as a voluntary set of principles. ${ }^{69}$ It was a weak set of general principles. Article 1 of the International Undertaking sets forth its fundamental operating concept: "The Undertaking is based on the universally accepted principle that plant genetic resources are a heritage of mankind and consequently should be available without restriction., That a commons approach to plant genetic resources as a "universally accepted principle" in 1983, the year that the International Undertaking was adopted, is debatable. The UPOV Convention, which came into force in 1961, provides that countries may provide for a sui generis right in plant varieties known as plant breeders' rights. Plant breeders are located mainly in the developed countries. 1 This presented a set of property rules in which plant genetic resources that were not worked by breeders were commons property free for the taking, while plant genetic 
resources that were worked into a breeder's right enjoyed protection.2 Resolution 4/89 of the International Undertaking, agreed during an 11-29 November 1989 FAO Conference, states that "Plant Breeders' Rights, as provided for under UPOV . . . are not incompatible with the International Undertaking," but Resolution 5/89, adopted in the same conference, endorsed the concept of Farmers' Rights, which are "rights arising from the past, present and future contributions of farmers in conserving, improving, and making available plant genetic resources, particularly those in the centres of origin/diversity." As the FAO explains:

Throughout the world, farmers and their communities have developed a vast portfolio of genetic diversity within crops and other plant species, which form the raw material for all agricultural activity. Modern plant breeding, in fact, builds on plant germplasm resources that have been traditionally developed and donated by farmers. Over the millennia, crops have been shared between regions, so that all countries are now interdependent, in that they rely for agriculture and food security, on crops that are cultivated elsewhere.

The International Treaty grew from the International Undertaking and seven years of negotiations. Signed in November 2001, it has yet to come into force. It will come into force on the ninetieth day after the fortieth ratification, acceptance, approval or accession. ${ }^{05}$ As of the date of this writing, the FAO has received thirty-three instruments of ratification, acceptance, approval or accession, $\frac{66}{6}$ so the Treaty is likely to come into force soon. The Treaty has the potential to become the most important among the array of agreements that deal with intellectual property and biodiversity, though its first article identifies the need for integration with the CBD. The objectives of the Treaty include "the fair and equitable sharing of the benefits arising" from the use of plant genetic resources, "in harmony with" the CBD. 97 Treaty objectives "will be attained by closely linking" the Treaty to the CBD. 98 Commentators have described the "most noteworthy feature" of the International Treaty, 29 its "central achievement," 100 its "multilateral 
system." The multilateral system is the key access provision of the International Treaty. The multilateral system provides for "facilitated access" to plant genetic resources. The relevant plant genetic resources are comprised of a list of key food and feed crops, identified in Annex 1 to the International Treaty. The genetic resources for these crops are held in seed banks. Private persons have access to the plant materials for the crops on the list, but if they commercialize products from the materials they must pay a percentage of profits to a trust account, and the trust funds must be used for fair and equitable benefit sharing through "information exchange, technology transfer, capacity building and allocation of monetary benefits from commercialization." 1010 The details are suppressed here in the interests of brevity, including the requirements of material transfer agreements, $\frac{102}{b u t}$ one more point bears mention. Article 12.3(d) provides that access is conditioned on the following: "Recipients shall not claim any intellectual property or other rights that limit the facilitated access to the plant genetic resources for food and agriculture, or their genetic parts or components, in the form received from the Multilateral System. ${ }^{103}$ The scope of this language will be one of the more interesting questions for implementation once the Treaty is in force.

\section{CONCLUSION}

Which approach is the more sound? Should there be more or fewer intellectual property rights in plant genetic resources? A general yes or no answer probably does not exist. The question cannot be answered in the absence of rigorous empirical investigation. As a recent study prepared for the European Commission explains, "[a]t present, there is no data that convincingly links IPRs to improved conservation of genetic resources. There is not even convincing data that situates IPRs into a more effective policy environment to conserve genetic 
resources." 104 The research needs to be done. It need not be strictly quantitative and reliant on econometric techniques. Case studies and qualitative surveys, using techniques from new institutional economics, may be helpful. Second, there may be no general answer to this question even if we had better information. Intellectual property approaches may work in some cases and not in others.

What is the goal? The answer to this question will determine one's position on the subject. If one's goal is to conserve biodiversity so that we can use it to maximize human welfare, then one might be more inclined to grant intellectual property rights and not worry too much about indigenous communities. If we were to adopt an economic approach (a kind of consequentialism), then we would ask how we would maximize the benefits of biodiversity at the point where social benefits equal social costs. In this economic calculus, we may be willing to sacrifice some biodiversity, if the cost of preserving it exceeds the benefits of preservation. Deontologists object to these approaches, claiming that it is morally wrong to use technologies developed by others without compensation, and that it is wrong to harm biodiversity to make humans who happen to live in this time period better off. These sorts of questions are of a threshold nature and must be dealt with before we attempt serious answers to the question whether or not intellectual property rights are advantageous or not.

What we do know at this point is that there are a variety of sometimes competing and sometimes coordinating international arrangements that say various things about intellectual property rights and biodiversity. Though it would seem that the trend is towards commercialization and more property rights, ${ }^{105}$ it remains to be seen whether the CBD and the 
new FAO International Treaty will produce substantial benefit sharing regimes that account for the interests of stakeholders beyond those recognized in traditional intellectual property rights.

\footnotetext{
* Associate Professor of Law, University of La Verne College of Law, Ontario, California USA. Portions of this article have appeared in J. Linarelli, "TRIPS, Biotechnology and the Public Domain: What Role will World Trade
} Law Play?, in C. Rodgers \& M. Cardwell eds., Agriculture and International Trade: Law, Policy and the WTO (CABI: Oxford 2003); J. Linarelli, "Trade Related Aspects of Intellectual Property Rights and Biotechnology: European Aspects,” (2002) 6 Singapore Journal of International and Comparative Law 406.

${ }^{1}$ UPOV Convention, http://www.upov.int/en/publications/conventions.

${ }^{2}$ http://www.fao.org/ag/cgrfa/IU.htm.

${ }^{3}$ http://www.fao.org/ag/cgrfa/itpgn.htm.

${ }^{4}$ http://www.biodiv.org/convention/articles.asp.

${ }^{5}$ L. Helfer, "Regime Shifting: The TRIPS Agreement and New Dynamics of International Intellectual Property Lawmaking," (2004) 29 Yale Journal of International Law (forthcoming).

${ }^{6}$ CBD Art 1.

${ }^{7}$ CBD Art 2.

8 James Boyle, "The Second Enclosure Movement and the Constitution of the Public Domain," http://www.law.duke.edu/pd/papers/boyle.pdf; Hannibal Travis, "Pirates of the Information Infrastructure: Blackstonian Copyright an the First Amendment, (2000) 15 Berkeley Technology Law Journal 777.

${ }^{9}$ Boyle, supra_n._.

${ }^{10}$ Ibid.

${ }^{11}$ Charlotte Hess \& Elinor Ostrom, “Artifacts, Facilitator, and Content: Information as a Common Pool Resource," http://www.law.duke.edu/pd/papers/ostromhess.pdf

${ }^{12}$ Press Release: United Nations meeting showcases the importance of preservation of traditional knowledge of indigenous and local communities. 
${ }^{13}$ Ibid.

${ }^{14}$ CBD Art. 2.

${ }^{15}$ quoted at http://ceres.ca.gov/biodiv/Biodiversity/biodiv_def2.html

${ }^{16}$ Ibid.

${ }^{17}$ Ibid.

${ }^{18}$ Ibid.

19 D.B Jensen, M. Forn \& J. Harte, "In Our Own Hands: A Strategy for Conserving Biological Diversity in California," (1990), quoted at http://caves.ca.gov/biodiv/Biodiversity/biodiv_dov2..html.

${ }^{20}$ World Resources Institute, supra n._.

${ }^{21}$ Ibid.

${ }^{22}$ Ibid.

${ }^{23}$ For discussion see [cite]

${ }^{24}$ L.B. Solum, “To Our Children's Children’s Children: The Problems of Intergenerational Ethics,” (2001) Loyola Los Angeles Law Review 163.

${ }^{25}$ R. Hursthouse, On Virtue Ethics (Oxford University Press: Oxford 2002).

${ }^{26}$ See e.g., Solum, supra $\mathrm{n}$.

${ }^{27}$ CBD Preamble.

${ }^{28}$ S.B. Brush, "Whose Knowledge, Whose Genes, Whose Rights?," in S.B. Brush \& D. Stabinsky (eds.), Valuing Local Knowledge: Indigenous People and Intellectual Property Rights (Island Press: Washington DC 1996).

${ }^{29}$ See infra p. _._.

${ }^{30}$ See John Rawls, A Theory of Justice (Belknap Press rev. ed. 1999).

31 R. F. Blomquist, "Ratification Resisted: Understanding America’s Response to the Convention on Biological Diversity," (2002) 32 Golden Gate University Law Review 493.

${ }^{32}$ Ibid.

${ }^{33}$ See CBD article 36.1 (on entry into force); http://biodiv.org/world/parties.asp (list of contracting parties). 
${ }^{34}$ http://www.boidiv.org/biosafety/dafault.aspx.

${ }^{35}$ CBD Preamble.

${ }^{36}$ Ibid.

${ }^{37}$ Ibid.

${ }^{38}$ Ibid.

${ }^{39} \mathrm{CBD}$ Article 1.

${ }^{40}$ In-situ conservation refers to "the conservation of ecosystems and natural habitats and the maintenance and recovery of viable populations of species in their natural surroundings and, in the case of domesticated or cultivated species, in the surroundings where they have developed their distinctive properties.” CBD Art. 2.

${ }^{41}$ CBD Art. 8(j).

${ }^{42}$ CBD Art. 10(c).

${ }^{43}$ C.R. McManis, "The Interface Between International Intellectual Property and Environmental Protection: Biodiversity and Biotechnology,” (1998) 76 Washington University Law Quarterly 255.

${ }^{44}$ Ibid.

${ }^{45}$ CBD Art. 3.

${ }^{46}$ CBD Art. 15.1.

${ }^{47}$ CBD Art. 15.5

${ }^{48}$ CBD Art. 15.7.

${ }^{49}$ CBD Art. 19.1

${ }^{50}$ CBD Art. 19.2

${ }^{51}$ Ibid.

${ }^{52}$ McManis, supra $\mathrm{n}$.

${ }^{53}$ CBD Art. 16.2.

${ }^{54}$ CBD Art. 21.

${ }^{55}$ CBD Art. 16.5. 
${ }^{56}$ CBD Art. 16.2.

${ }^{57}$ CBD Art. 16.3.

${ }^{58} \mathrm{http} / / /$ www.biodiv.org/programmers/sacto-eco/benefit/bonn.asp.

${ }^{59}$ M. Jeffery, Q.C., "Bioprospecting: Access to Genetic Resources and Benefit-Sharing under the Convention on Biodiversity and the Bonn Guidelines,” (2002) Singapore Journal of International \& Comparative Law 1.

${ }^{60}$ Bonn Guidelines, supra $\mathrm{n}$. _..

${ }^{61}$ Ibid.

${ }^{62}$ Ibid.

${ }^{63}$ Ibid.

${ }^{64}$ Ibid.

${ }^{65}$ Ibid.

${ }^{66}$ Ibid.

${ }^{67}$ Ibid.

${ }^{68}$ Ibid.

${ }^{69}$ Ibid.

${ }^{70}$ F. Abbott, "TRIPS in Seattle: The Not-So-Surprising Failure and the Future of the TRIPS Agenda," (2000) 18 Berkeley Technology Law Journal 165); W. A. Dymond \& Michael M Hart, 'Post Modern Trade Policy: Reflections on the Challenges to Multilateral Trade Negotiations After Seattle', (2000) 34 Journal of World Trade 21

${ }^{71}$ Carliene Brenner, "Intellectual Property Rights and Technology Transfer in Developing Country Agriculture: Rhetoric and Reality," (1998) OECD Technical Papers No 133; Phillip McMalman, 'Reaping What you Sow: An Empirical Analysis of International Patent Harmonization,' (December 1999), econ.ucsc.edu/faculty/mccalman/wkpaper.html; Keith Maskus, “ Lessons from Studying the International Economics of Intellectual Property Rights," (2000) 53 Vanderbilt Law Review 2219.

72 TRIPS Art. 27.1

${ }^{73}$ Ibid. 
${ }^{74}$ TRIPS Art. 27.2

${ }^{75}$ TRIPS Art. 27.3

${ }^{76}$ Ibid.

${ }^{77}$ TRIPS Art. 30.

${ }^{78}$ M. Llewelyn, "PIP Project and Legislative Overview," Conference on Plant Intellectual Property Within Europe and the Wider Global Community,” http://shef.ac.uk/ pip/session1.doc

${ }^{79}$ European Patent Convention Art. 53.

${ }^{80}$ European Patent Convention Art. 64.

${ }^{81}$ European Patent Convention Art. 53(b).

${ }^{82}$ R. Nott, "The Novartis Case in the EPO,” (1999) 21 European Intellectual Property Review 33.

${ }^{83}$ Ibid.

${ }^{84}$ European Patent Convention Art. 53(a).

85 T. Millett, “The Community System of Plant Variety Rights, (1999) 24 European Law Review 231.

${ }^{86}$ UPOV Convention Art. 2.

${ }^{87}$ In the EU member states the Council Regulation on Community Plant Variety Rights still provides that in the EU, plant variety rights are "the sole and exclusive form of Community industrial property rights for plant varieties." Council Regulation Article 1.

${ }^{88}$ G. Rose, "International Law of Sustainable Agriculture in the $21^{\text {st }}$ Century: The International Treaty on Plant Genetic Resources for Food and Agriculture," (2003) 15 Georgetown International Environmental Law Review 583.

${ }^{89}$ Ibid.

${ }^{90}$ International Undertaking Art. 1

${ }^{91}$ K. Raustiala \& D. G. Victor, "The Regime Complex for Plant Genetic Resources," SSRN Research Paper No. 0319, http://ssrn.com/abstract=441463.

${ }^{92}$ Ibid. 
${ }^{93}$ International Undertaking, Annex II.

${ }^{94}$ Farmers' Rights.

${ }^{95}$ International Treaty Art. 28.1

${ }^{96}$ INTERNATIONAL TREATY ON PLANT GENETIC RESOURCES

${ }^{97}$ International Treaty Art. 1.1.

${ }^{98}$ International Treaty Art. 1.2.

${ }^{99}$ L. R. Helfer, "Intellectual Property Rights and the International Treaty on Plant Genetic Resources for Food and Agriculture, (2003) 97 American Society of International Law Proceedings 33.

${ }^{100}$ Rose, supra n. _, at _..

${ }^{101}$ International Treaty Arts. __; Rose, supra n. _, at __.

${ }^{102}$ Helfer, supra n. _, at __

${ }^{103}$ International Treaty Art. 12.2(d).

${ }^{104}$ Padmashree Gehl Sampath \& Richard G. Tarasofsky, Study on the Inter-Relations between Intellectual Property Rights Regimes and the Conservation of Genetic Resources, Final Report, Prepared for the European Commission Directorate-General, Environment, 31 Dec. 2002, p. 53.

${ }^{105}$ Raustiala \& Victor, supra n. _. 